\title{
Aleš Maver \\ Veteres igitur primique Romani: rimsko kraljestvo in republika v zgodnji latinski krščanski apologetiki
}

I.

Avguštin je v Božjem mestu krščansko videnje zgodnje rimske zgodovine sorazmerno uspešno in zgoščeno povzel z naslednjimi besedami:

Veteres igitur primique Romani, quantum eorum docet et commendat historia, quamvis ut aliae gentes excepta una populi Hebraeorum deos falsos colerent et non Deo victimas, sed daemoniis immolarent, tamen »laudis avidi, pecuiniae liberales erant, gloriam ingentem, divitias honestas volebant«; hanc ardentissime dilexerunt, propter hanc vivere voluerunt, pro hac emori non dubitaverunt; ceteras cupiditates huius unius ingenti cupiditate presserunt. Ipsam denique patriam suam, quoniam servire videbatur inglorius, dominari vero atque imperare gloriosum, prius omni studio liberam, deinde dominam esse concupiverunt. (De civitate Dei 5.12)

Starodavni in prvi Rimljani so bili, kolikor nas poučuje in jih priporoča njihova zgodovina, čeprav so kot druga ljudstva $z$ edino izjemo hebrejskega rodu častili lažne bogove in daritev niso prinašali Bogu, marveč demonom, kljub vsemu »željni hvale in velikodušni z denarjem ter so si želeli velike slave in poštenega bogastva«. Slavo so nadvse goreče ljubili, zaradi nje so hoteli živeti in zanjo si niso pomišljali umreti. Ostala poželenja so zatrli z izjemno željo zgolj po njej. Naposled so, ker se jim je zdelo, da bi bilo za njihovo domovino samo nečastno hlapčevati, častno pa gospodovati in vladati, $\mathrm{z}$ vsem srcem hrepeneli najprej po tem, da bi bila svobodna, nato pa po tem, da bi bila gospodarica. 
Njegova ocena se nam lahko upravičeno zdi sladko-kisla. V isti sapi, ko po Salustiju ${ }^{1}$ povzema podatke o krepostnosti junakov prvih stoletij rimske zgodovine, krščanskemu navdušenju nad njimi doda odločilno omejitev z opozorilom, da so se vsi omadeževali s čaščenjem nepravih bogov. Pozneje svojo misel še podkrepi, ko nanje naveže Jezusovo mnenje o farizejih in pismoukih, češ da so že "prejeli svoje plačilo«. ${ }^{2}$ A kljub temu je Avguštinovo ovrednotenje tako rekoč največ, kar so bili krščanski apologeti pripravljeni priznati dosežkom Rimljanov v obdobju pred nastopom cesarstva.

Omenjeno dejstvo korenini že v spisih pionirjev latinske apologetike, od katerih je hiponski škof seveda tudi sicer pobral marsikaj. ${ }^{3}$ Kar zadeva zgodovinske teme, je sicer tako, da je najti pri zgodnjih apologetih zgolj bolj ali manj raztresene (resda vplivne) drobce. ${ }^{4}$ Ta trditev še tem bolj velja za obdobje rimskega kraljestva in rimske republike. Kar nekaj razlogov je, zaradi katerih je bilo za krščanske pisce manj privlačno. Najbolj prozaičen med njimi je bržkone ta, da gre za obdobje, ko krščanstva preprosto še ni bilo (po drugi strani pa ta čas znova ni bil dovolj oddaljen, da bi si bilo mogoče z njim kaj prida pomagati pri dokazovanju časovne prednosti judovstva in krščanstva).

Ključno je bilo nadalje, da v univerzalističnem krščanskem pojmovanju zgodovine, za katerega je bil v celoti gledano najpomembnejši koncept prenašanja kraljestev (translatio imperii), ${ }^{5}$ relativno obrobno poglavje zgodnje zgodovine Rima ni moglo biti prav konkurenčno. Bistveno vlogo je - kar je razvidno že iz navedka iz Božjega mesta - odigralo tudi povezovanje prvih rimskih stoletij z vzpostavitvijo in razcvetom poganstva. Kot bo razvidno v nadaljevanju, je omenjena povezava posebej pomembna za Minucija Feliksa.

Slednjič so kristjani, čeprav je verjetno upravičena opazka, da so se bolj kot $\mathrm{z}$ abstraktnimi koncepti državne ureditve ukvarjali s konkretnimi nosilci oblasti, ${ }^{6}$ velikokrat poudarjali svojo zvestobo monarhični ureditvi cesarske dobe, saj so ravno v izročilih, temelječih na idealizirani podobi zgodnje rimske zgodovine, gledali glavno jedro sovražnosti do krščanstva. Omenjeno je izpostavil denimo Tertulijan, ko je zapisal:

Unde Cassii et Nigri et Albini? Unde qui inter duas laurus obsident Caesarem? Unde qui faucibus eius exprimendis palaestricam exercent? Unde qui armati palatium irrumpunt, omnibus tot Sigeriis atque Partheniis audaciores? De Romanis, nisi fallor, id est de non Christianis. Atque adeo omnes illi sub ipsa usque impietatis eruptione et sacra faciebant pro salu-

\footnotetext{
V odlomku gre za: Salustij, De coniuratione Catilinae, 7.6.

Prim. o tem D’Elia, »Storia e teologia della storia«, 442 in sl.

O njegovi vraščenosti v tradicijo latinske apologetike mdr. O'Daly, Augustine's City of God, 39-52.

4 O njih pregledno Meinhold, Geschichte der kirchlichen Historiographie, zlasti 42-74.

Winkelmann, »Historiographie«, 748; Zecchini, »Latin Historiography«, 321.

Leppin, »Politik und Pastoral«, 310 in sl.
} 
te imperatoris et genium eius deierabant, alii foris, alii intus, et utique publicorum hostium nomen Christianis dabant. (Apologeticum 35.9-10)

Odkod so Kasiji in Nigri in Albini? Odkod so ti, ki med dvema lovorovima vencema zalezujejo cesarja? Odkod so tisti, ki se razgibavajo tako, da mu režejo vrat? Odkod so tisti, ki oboroženi vdirajo v palačo, predrznejši od vseh Sigerijev in Partenijev? Iz vrst Rimljanov, če se ne motim, to pomeni, iz vrst nekristjanov. Vsi ti pa so, vse dokler ni izbruhnila njihova brezbožnost, opravljali obrede za cesarjev blagor in prisegali pri njegovem geniju, nekateri javno, drugi sami zase, in kajpak nadevali kristjanom naslov državnih sovražnikov.

Zaradi vsega doslej navedenega ni nič čudnega, da prva obsežnejša prikaza pionirskega obdobja Rima v apologetskem ali vsaj delno apologetskem spisju spadata na začetek 5. stoletja, nekako v čas tedaj, ko je bila zgodovina republike izjemno priljubljena tudi pri poganih. ${ }^{7}$ Povedno in skladno s cilji obeh piscev, ki sta zanju zaslužna, je, da se pri Avguštinu tehtnica v primerjavi med republiko in cesarstvom vsaj blago nagne v prid prvi, ${ }^{8}$ medtem ko je pri Oroziju nesporni zmagovalec mlajše obdobje. ${ }^{9}$

V spisih, ki se jim bom posvetil v nadaljevanju, tj. v Tertulijanovih Apologetiku in De spectaculis, v Minucijevem Oktaviju in v Arnobijevem delu Adversus nationes, so omembe oseb in dogodkov iz časa kraljev in republike potemtakem v vlogi statistov. Njihova interpretacija je razen tega povsem $\mathrm{v}$ službi aktualne polemike, kar lahko, kot bo še postalo jasno, privede tudi do navidezno paradoksne posledice, da ima ista danost v različnih kontekstih zelo različne vrednostne oznake.

II.

Nabor tem iz zgodnje rimske zgodovine je primerno skromen. Hkrati se da hitro ugotoviti, da apologeti mitološki zgodovini iz obdobja kraljev iz bržčas razumljivih razlogov vsaj na prvi pogled posvečajo več pozornosti kot zgodovinsko otipljivejšemu obdobju republike. Med figurami rimskih kraljev izstopata Romul, ki daje prvim latinsko pišočim krščanskim teologom dokaj snovi z okoliščinami svojega ustanoviteljskega dejanja, a tudi z načinom svoje smrti, in Numa Pompilij kot poglavitni mitološki verski inovator. ${ }^{10}$ Ostali kralji in akterji republikanske zgodovine imajo manj viden položaj, še največkrat na

Rohrbacher, The Historians of Late Antiquity, 179 in sl.

8 Inglebert, Les Romains chrétiens, 497.

9 Rohrbacher, The Historians of Late Antiquity, 141 in sl.

10 O ozadju te Numove vloge zdaj zanimivo razmišlja Forsythe, A Critical History of Early Rome, predvsem 97. 
sceno stopi junak prve punske vojne Atilij Regul (ki svojo slavo ohrani še pri Avguštinu). Omembe obdobja pozne republike so še bolj naključne kot tiste zgodnejših časov.

Kar zadeva apologetsko vrednotenje v pripoved in argumentacijo pritegnjenih pojavov, naj se najprej ustavim ob zgledih, za katere bi lahko rekli, da sta $\mathrm{v}$ njih zgodovina kraljev in republike prikazana $\mathrm{v}$ ugodni luči. Kakor je razvidno iz navedka iz Božjega mesta $\mathrm{z}$ začetka besedila, je bila verjetno bistvena privlačnost tega obdobja za kristjane $\mathrm{v}$ domnevni nepokvarjenosti njegovih akterjev. ${ }^{11} \mathrm{~V}$ opozarjanju nanjo prednjači Tertulijan. Že v enem od začetnih poglavij Apologetika na ta način ubije dve muhi na en mah. Svojim fiktivnim poganskim sogovornikom namreč poočita, da sicer rohnijo zoper kristjane $\mathrm{v}$ imenu izročil prednikov, vendar se sami tovrstnih izročil prav nič ne drže, ne samo, kar se tiče starodavnim Rimljanom tako ljube skromnosti, marveč tudi, kar zadeva pravo (pogansko) bogočastje. Svojo kanonado jezični Afričan začne $\mathrm{z}$ navajanjem zgledom nekdanjega omejevanja razkošja in $\mathrm{z}$ namigovanjem na drugačno prakso sodobnikov:

Nunc religiosissimi legum et paternorum institutorum protectores et ultores respondeant velim de sua fide et honore et obsequio erga maiorum consulta, si a nullo desciverunt, si in nullo exorbitaverunt, si non necessaria et aptissima quaeque disciplinae oblitteraverunt. Quon[i]am illae leges abierunt sumptum et ambitionem comprimentes, quae centum aera non amplius in cenam subscribi iubebant, nec amplius quam unam inferri gallinam, et eam non saginatam, quae patricium, quod decem pondo argenti habuisset, pro magno ambitionis titulo senatu submovebant, quae theatra stuprandis moribus orientia statim destruebant, quae dignitatum et honestorum natalium insignia non temere nec impune usurpari sinebant? Video enim et centenarias cenas a centenis iam sestertiis dicendas, et in lances - parum est, si senatorum et non libertinorum vel adhuc flagra rumpentium - argentaria metalla producta. Video et theatra nec singula satis esse nec nuda. (Apologeticum 6.1-3)

Zdaj pa prosim, naj podajo prespoštljivi varuhi in branitelji postav in očetnih uredb račun o svoji zvestobi, svojem spoštovanju in svoji pokorščini do sklepov svojih prednikov, če se niso nobenemu izneverili, če se niso od nobenega odmaknili, če niso pozabili ničesar, kar je potrebno in koristno za nravnost. Kam so odšle postave, ki so zatirale potratnost in častihlepnost; tiste, ki so velevale, da za večerjo ni dovoljeno potrošiti več kot sto asov, da se na mizo ne sme postaviti več kot ene kokoši, pa še ta naj ne bo pitana. Kje je tista postava, ki je zaradi prevelike bahavosti iz senata izključila Patricija, ker je imel deset funtov srebrnine; tista, ki je

11 Kot med drugim ugotavlja Inglebert, Les Romains chrétiens, 86. 
gledališča, škodljiva dobrim nravem, dala pri priči podreti; tista, ki ni dovolila, da bi si bil kdo predrzno in nekaznovano lastil znamenja dostojanstev in plemenitega rojstva? Vidim namreč, da je treba »večerjo za sto« danes poimenovati po sto tisoč sestercih in da srebrno kovino predelujejo v sklede - kaj za senatorje, za osvobojence ali celo za take, na katerih se trgajo še biči. Vidim tudi, da ni več dovolj eno in nepokrito gledališče.

Če so v odlomku glavni predmet apologetove hvale različne republikanske leges sumptuariae, med katerimi je imela odlično mesto Lex Fannia iz leta 161 pr. Kr. o omejevanju stroškov za pojedine, ${ }^{12}$ in pri apologetih zelo priljubljeno porušenje prvega kamnitega gledališča leta 185 pr. Kr., ${ }^{13}$ v nadaljevanju izvore takšnega odnosa do potrate in uživaštva poišče kar pri samem ustanovitelju Rima Romulu. Navede namreč tudi od Valerija Maksima (6.3.9) znani eksempel, da je smel za časa njegove vlade Metenij nekaznovano ubiti svojo ženo, ker se je dotaknila vina (Apologeticum 6.4). Medtem ko si drzne Valerij Maksim celo blago podvomiti o sorazmernosti zločina in kazni, krščanski pisec moževega dejanja z ničimer ne postavi pod vprašaj. ${ }^{14}$ Za sklep pa si Tertulijan kajpak prihrani očitek poganom, da pravzaprav sami počnejo tisto, kar najbolj oporekajo kristjanom in sprevračajo celo predpise tolikokrat na piedesetal postavljenih prednikov na področju kulta:

Etiam circa ipsos deos vestros quae prospecte decreverant patres vestri, idem vos obsequentissimi rescidistis. Liberum Patrem cum mysteriis suis consules senatus auctoritate non modo urbe, sed universa Italia eliminaverunt. Serapidem et Isidem et Arpocratem cum suo Cynocephalo Capitolio prohibitos inferri, id est curia deorum pulsos, Piso et Gabinius consules, non utique Christiani, eversis etiam aris eorum abdicaverunt, turpium et otiosarum superstitionum vitia cohibentes. His vos restitutis summam maiestatem contulistis. (Apologeticum 6.7-8)

Tudi tisto, kar so vaši očetje previdno ukrenili glede vaših bogov, ste vi, njihovi preposlušni sinovi, razveljavili. Očeta Libera z njegovimi misteriji so konzuli s senatovo avtoriteto pregnali ne samo iz mesta Rima, marveč iz vse Italije. Serapisa, Izido in Arpokrata z njegovo pasjo glavo, ki jim je bil vstop na Kapitol prepovedan, se pravi, da so bili izgnani iz zbora bogov, sta konzula Pizon in Gabinij - seveda ne kristjana - zavrgla, potem ko sta podrla tudi njihove oltarje, da bi preprečila pregrehe, ki jih rodi sramotno in brezdelno praznovanje. Slednje ste vi zopet uvedli in jim podelili najvišje dostojanstvo.

12 Gl. denimo Gelij, Noctes Atticae 2.24.5. O Tertulijanovem odnosu do tovrstne zakonodaje prim. še Inglebert, Les Romains chrétiens, 87.

13 O katerem navdušeno poroča še Avguštin, De civitate Dei 1.31 .

14 Von Haehling, »Die römische Frühzeit«, 187 z op. 20. 
Iz celotnega šestega poglavja torej diha izrazito pozitiven odnos do zgodnjih stoletij rimske zgodovine, ki se od krepostnih republikanskih časov razširi še na čas kraljestva. Takšen odnos je ob obravnavi zgodnje zgodovine gledališča $\mathrm{v}$ Rimu viden še v ( $\mathrm{v}$ prvi vrsti Tertulijanovim sokristjanom namenjenem ${ }^{15}$ ) spisu De spectaculis. Tam afriški apologet spet hvali občutljivost prednikov za morebitna legla moralne razpuščenosti:

Saepe censores nascentia cum maxime theatra destruebant moribus consulentes, quorum scilicet periculum ingens de lascivia providebant, ut iam hinc ethnicis in testimonium cedat sententia ipsorum nobiscum faciens et nobis in exaggerationem disciplinae etiam humana praerogativa. Itaque Pompeius Magnus solo theatro suo minor cum illam arcem omnium turpitudinum extruxisset, veritus quandoque memoriae suae censoriam animadversionem Veneris aedem superposuit et ad dedicationem edicto populum vocans non theatrum, sed Veneris templum nuncupavit, cui subiecimus, inquit, gradus spectaculorum. (De spectaculis 10.4 in sl.)

Cenzorji so pogosto dali porušiti nastajajoča gledališča, saj so skrbeli za nravi, o katerih so predvidevali, da predstavljali zanje razuzdanost velikansko nevarnost. Tako je že njihovo mnenje, ki je voda na naš mlin, pričevanje za pogane in naš nauk utrjujejo tudi človeški glasovi. Zato je Pompej Veliki, manjši le od svojega gledališča, ko je dal zgraditi to trdnjavo vseh ostudnosti, nadnjo postavil Venerino svetišče, ker se je bal, da bi spomin nanj nekoč omadeževala cenzorska graja. In ko je ljudstvo z razglasom povabil na otvoritev, stavbe ni imenoval gledališče, temveč Venerino svetišče, ki smo mu, kot pravi, dodali sedeže za predstave.

Vendar je kontekst pohvale, ki jo razbiramo iz oznake moribus consulentes in iz opozarjanja na njihovo pravilno ocenjevanje kvarnih vplivov, zdaj precej drugačen. Zgled sodi pač v obširni sklop dokazovanja (poganskih) kultnih korenin vseh na muho vzetih javnih prireditev, zaradi česar naj bi bile slednje za kristjana že same na sebi prepovedan sad. In Pompej prepoved gradnje gledališča zaobide prav s kultno kamuflažo v podobi boginje Venere. $\mathrm{Na}$ ta način ne more biti govora o pozitivni sliki republikanske dobe kot take (saj ji navsezadnje pripada pobudnik gradnje kultno in moralno obremenjene ustanove, ki ima za nameček malikovalski pečat), v okviru polemike zoper vsakršno obliko javne zabave pa pride Tertulijanu sklicevanje na podobna stališča starodavnih poganov kljub vsemu še kako prav.

Nekaj podobnega bi se dalo nedvomno reči ob evhemeristično navdahnjenem Tertulijanovem katalogu ${ }^{16}$ junakov iz republikanskega obdobja rimske

15 Kot izrecno poudari von Haehling, "Die römische Frühzeit«, 189.

16 O evhemerizmu pri Tertulijanu prim. denimo Thraede, »Euhemerismus «, predvsem 887, in Maver, »Pota in stranpota «, 28 in sl. 
zgodovine, ki jih naslovnikom svojega spisa nekako ponuja kot ustreznejše kandidate za apoteozo od dejansko čaščenih božanstev, po evhemerističnih predpostavkah sprva ravno tako ljudi. Katalog je videti takole: »Quis ex illis deis vestris gravior et sapientior Catone, iustior et militatior Scipione? Quis sublimior Pompeio, felicior Sylla, copiosior Crasso, eloquentior Tullio? (Apologeticum 11.16.)

Seveda bi bilo moč sklepati, da Tertulijan z navedenimi vrsticami še enkrat več priznava zgodovini republike izredno krepostnost njenih akterjev. Toda vse se zadržuje v precej ozkih mejah prizadevanja za to, da bi pokazal popolno nevrednost in neprimernost obstoječega poganskega panteona. Da bi imela njegova ocena omenjanih figur kakšno samostojno vrednost, bi bilo bržčas pretirano trditi. Nenazadnje zato, ker se nekaterih med navedenimi odlikami niti ne da brez ostanka razglasiti za kreposti, kakor bi se še dalo ob zgledih iz nekaterih prejšnjih poglavij spisa.

Teološko najbrž vznemirljivejše je naslednje polje, na katerem so zgodnji latinski apologeti pozitivno slikali posameznike iz pradavnih stoletij Rima. Slednji so se pač izkazali za primerne za mobilizacijo v poskusih razprševanja enega najneprijetnejših poganskih očitkov, češ da kristjani častijo na križu usmrčenega tesarja, ne menijo pa se za cesarski kult. ${ }^{17} \mathrm{Na}$ podoben način se je dalo z izbranimi zgledi iz obdobja kraljestva in republike nekrščanski okolici približati fenomen krščanskega mučeništva (predvidevamo sicer lahko, da v glavnem neuspešno). ${ }^{18}$

Za današnjega bralca najbrž banalno opravičevanje Kristusove smrti na križu z zgledi na prav tako mučen način umrlih junakov grško-rimskega sveta (in bogov) je najbolj izpilil Arnobij iz Sike. Kar v prvi knjigi svoje obsežne apologije Adversus nationes ${ }^{19}$ postreže, preden preide k bogovom, s katalogom tovrstnih oseb, ki naj bi delale krščanski kult razumljivejši:

"Sed patibulo adfixus interiit." - Quid istud ad causam? Neque enim qualitas et deformitas mortis dicta eius immutat aut facta, aut eo minor videbitur disciplinarum eius auctoritas, quia vinculis corporis non naturali dissolutione digressus est sed vi inlata decessit. Pythagoras Samius suspicione dominationis iniusta vivus concrematus in fano est: numquid ea quae docuit vim propriam perdiderunt, quia non spiritum sponte sed crudelitate adpetitus effudit? Similiter Socrates civitatis suae iudicio damnatus capitali adfectus est poena: numquid inrita facta sunt quae sunt ab eo de moribus virtutibus et officiis disputata, quia iniuria expulsus e vita est? Innumerabiles alii gloria et virtute et existimatione pollentes acerbissimarum mortium experti sunt formas, ut Aquilius Trebonius Regulus:

17 O tem dobro Koep, »Antikes Kaisertum und Christusbekenntnis«, 302-36.

18 Posebej odločno v tej smeri Heck, Mè theomáchein, 14.

19 Med novejšo literaturo o njej naj omenim Simmons, Arnobius of Sicca, in Edwards, »Flowering of Latin Apologetic«, 197-221. 
numquid idcirco post vitam iudicati sunt turpes, quia non publica lege fatorum sed mortis asperrimo genere lacerati excruciatique perierunt? Nemo umquam innocens male interemptus infamis est, nec turpitudinis alicuius conmaculatur nota, qui non suo merito poenas graves sed cruciatoris perpetitur saevitatem. (Arnobius, Adversus nationes 1.40)

»A je umrl pribit na križ. « Kaj ima to opraviti s stvarjo? Način in odurnost njegove smrti namreč ne spremenita njegovih besed ali dejanj, veljava njegovih naukov pa se ne zdi nič manjša zaradi tega, ker s sveta ni odšel $\mathrm{z}$ naravno razvezo, marveč je preminil nasilne smrti. Pitagora s Samosa so, ker so ga po krivici sumili želje po oblasti, živega sežgali v svetišču. Mar je tisto, kar je učil, izgubilo svojo moč, ker duha ni izročil prostovoljno, marveč pod vplivom okrutnosti? Podobno je Sokrat po razsodbi svojega mesta pretrpel smrtno kazen. Mar so dejstva o nraveh, vrlinah in dolžnostih, o katerih je razpravljal, zmotna, ker ga je iz življenja pregnala krivica? Še neštevilni drugi, ki so se odlikovali po slavi, kreposti in ugledu, so doživeli najhujše oblike smrti, kakor denimo Akvilij, Trebonij in Regul. So mar po smrti zaradi tega nanje gledali kot na nečastne ljudi, ker niso preminili po splošnem zakonu usode, temveč so po mesarjenju in mučenju vzeli prebridek konec? Nihče, ki je bil kdaj nedolžen grozovito pokončan, ni zloglasen, in tisti, ki ne pretrpi zaslužene hude kazni, ampak mučiteljevo divjaštvo, ni omadeževan z nobenim sramotnim znamenjem.

Kot spričevalo, da način smrti ne razveljavi življenjskega dela umrlega, je v ugledno družbo Pitagore in Sokrata postavil že od predhodnikov med apologeti znana Regula iz časa prve punske vojne in Akvilija iz časa vojn z Mitridatom. Manj običajna je uvrsitev v katalog zarotnika proti Cezarju in poznejše žrtve Dolabelove izdaje Trebonija, ki glede na svojo biografijo v krščanskem main streamu verjetno ni mogel veljati za neoporečno figuro. Jasno je, da Arnobij podobno kot Tertulijan udom svojega kataloga ne pripisuje kakšnega posebnega lastnega pomena, kaj šele, da bi z njihovo omembo pripisal posebno težo obdobju njihovega življenja in delovanja. Ob rimskih osebnostih se mu ne zdi vredno niti orisati njihovih zaslug, zaradi česar se je verjetno že kak sodobnik spraševal, kaj Akvilij in Trebonij sploh počneta ob Sokratovem boku. Na kratko povedano se je apologet pač domislil vsaj napol uporabnih zgledov in jih ne bodi len nemudoma mobiliziral, ne da bi se pretirano spraševal o njihovem siceršnjem zgodovinskem kontekstu.

Ob povezovanju Kristusove usode $\mathrm{z}$ usodo uglednih smrtnikov iz bolj oddaljene preteklosti se je mogel Arnobij morda nasloniti na v obrisih nakazano podobnost med Jezusom iz Nazareta in Romulom, kot jo podaja Apologetik. Ob koncu krajšega pregleda Kristusovega življenja prvi latinski apologet namreč napiše: »Dehinc ordinatis eis ad officium praedicandi per orbem circumfusa nube in caelum est receptus multo verius quam apud vos adseverare 
de Romulo Proculi solent.«(Apologeticum 21.23). Primerjava ima sicer omejen domet, ker se Tertulijan po eni strani - drugače kot Arnobij v svojem katalogu - omalovaževalno izrazi o poganskem izročilu, po drugi strani pa še ne poveže Romulovega in Kristusovega umora.

Ravno tako se pri retorju iz Sike omenjena Akvilij in Regul več kot stoletje poprej resda pojavita v Oktaviju Minucija Feliksa, vendar z njima pisec ne opravičuje križanja, temveč poganom približuje fenomen krščanskega mučenca in spoštovanja, ki mu ga izkazujejo soverniki:

Vos ipsi calamitosos viros fertis ad caelum, ut Mucium Scaevolam, qui cum errasset in regem, perisset in hostibus, nisi dexteram perdidisset. Et quot ex nostris, non dextram solum, sed totum corpus uri, cremari sine ullis eiulatibus pertulerunt, cum dimitti praesertim haberent in sua potestate! Viros cum Mucio vel cum Aquilio aut Regulo comparo? Pueri et mulierculae nostrae cruces et tormenta, feras et omnes suppliciorum terriculas inspirata patientia doloris inludunt. Nec intellegitis, o miseri, neminem esse qui aut sine ratione velit poenam subire aut tormenta sine deo possit sustinere. (Minucius Felix, Octavius 37.3-6)

Vi sami kujete v nebo može, preizkušene v nesrečah, Mucija Scevolo, ki bi bil umrl med sovražniki, ker se je bil zmotil v kraljevi osebi, če ne bi bil izgubil desnice. In koliko naših jih je preneslo brez kakršnih koli krikov bolečine, da je celo telo, ne le desnica, gorelo, se žgalo, zlasti ko je bilo v njihovi moči, da bi bili oproščeni. Ali naj može primerjam z Mucijem ali Akvilijem ali Regulom? Naši dečki in ženice se posmehujejo križem in mučilom, divjim zverem in vsem zemeljskim kaznim $\mathrm{z}$ navdihnjenim prenašanjem bolečine. Ne razumete, o bedniki, da ni nikogar, ki bi hotel brez vzroka prevzeti kazen ali mogel brez Boga prenesti muke ${ }^{20}$

Zagotovo je v navedenih vrsticah eden lepših pomnikov republikanskim junakom v latinskem krščanskem slovstvu in v tem oziru Minucij Feliks presega podoben zaključek Apologetika (gl. Apologeticum 50), v katerem je Tertulijan veliko več pozornosti posvetil likom iz grške zgodovine, v prvi vrsti filozofom. Najbrž je umestno opažanje, da je avtor Oktavija z opozorilom na svetle zglede iz rimske preteklosti poskusil nekako omiliti vtis o svoji sovražnosti do rimskih izročil. ${ }^{21}$ Slednji bi zlahka nastal ob neusmiljenem apologetovem obračunu $z$ dogodki in osebami najstarejše rimske zgodovine, o čemer bo potrebno še kaj reči.

Zadnji teren, na katerem so mogli zgodnji latinski apologeti s pridom posegati po gradivu iz republikanske dobe in so mu obenem pridajali pozitivno konotacijo, je rimski republiki kot taki in njenim junakom še manj omogočal,

20 Navedeno v prevodu Jasne Hrovat.

21 Tako von Haehling, »Die römische Frühzeit«, 193. 
da bi zasijali kot kakšna vrednota sama po sebi. Govorim o obupnih poskusih zgodnjih krščanskih teologov, da bi ovrgli pogost poganski očitek, češ da je krščanstvo šele od včeraj in da predvsem predstavlja nedopustno versko novotarijo in hud odmik od izročil prednikov. ${ }^{22} \mathrm{Z}$ grškimi in republikanskimi zgledi za inovacije na pravnem področju si je v spopadu $\mathrm{z}$ omenjenim očitkom obilno pomagal že Tertulijan (gl. zlasti Apologeticum 4.6 in sl.), toda najbolj je po tem (za pogane ne pretirano prepričljivem) orožju spet posegal Arnobij. Proti koncu druge knjige Adversus nationes je tako postregel s pravo zbirko odmikov od običajev prednikov od začetkov Rima do svojih dni (med zgledi se je znašel tudi običaj poljuba kot preizkusa vinjenosti in prepoved pitja za ženske, ki ju v Apologetiku hvali Tertulijan):

Itaque cum nobis intenditis aversionem a religione priorum, causam convenit ut inspiciatis, non factum, nec quid reliquerimus opponere, sed secuti quid simus potissimum contueri. Nam si mutare sententiam culpa est ulla vel crimen et a veteribus institutis in alias res novas voluntatesque migrare, criminatio ista et vos spectat, qui totiens vitam consuetudinemque mutastis, qui in mores alios atque alios ritus priorum condemnatione transistis. Numquid enim quinque in classes habetis populum distributum, vestri olim ut habuere maiores? Numquid magistratus per populum creatis? militaria urbana communia quae sint comitia scitis? servatis de caelo aut otiosas facitis obnuntiationibus actiones? si paratis bella, signum monstratis ex arce? aut fetialia iura tractatis? Per clarigationem repetitis res raptas? Aut Martium discrimen obeuntes spem proelii sumitis et ex acuminibus auspicatis? In potestatibus obeundis leges conservatis annarias? In donis, in muneribus Cincias? In cohibendis censorias sumptibus? In penetralibus et caeligenis perpetuos fovetis focos? Sacras facitis mensas salinorum adpositu et simulacris deorum? Cum in matrimonia convenitis, toga sternitis lectulos et maritorum genios advocatis? Nubentium crinem caelibari hasta mulcetis? Puellarum togulas Fortunam defertis ad Virginalem? Matres familias vestrae in atriis operantur domorum industrias testificantes suas? Potionibus abstinent vini? Adfinibus et propinquis osculari eas ius est, ut sobrias comprobent atque abstemias se esse? (Arnobius, Adversus nationes 2.67)

Zato bi bilo, ker nam očitate odvrnitev od religije prednikov, primerno, da ste pozorni na vzrok, ne zgolj na dejstvo, da nam ne očitate tistega, kar smo zapustili, marveč se raje ozrete na tisto, čemur smo sledili. Če je namreč spremeniti mnenje in od starih običajev preiti $\mathrm{k}$ drugim, novim rečem in prizadevanjem kakšen prestopek ali zločin, potem se ta obtožba nanaša tudi na vas, ko ste vendar tolikokrat spremenili način življenja in nava-

${ }^{22}$ O resnosti tega očitka in njegovem vplivu na položaj kristjanov v rimski državi Fiedrowicz, Apologie im frühen Christentum, 209 in sl. 
de in po obsodbi prejšnjih prešli k drugim običajem in drugim obredom. Mar imate ljudstvo še vedno razdeljeno na pet razredov, kakor so ga nekoč imeli vaši predniki? Mar uradnike še vedno voli ljudstvo? Mar veste, kaj so vojaška, mestna in splošna skupščina? Še upoštevate nebo ali ob naznanilu slabih znamenj prekinete delovanje? Še vedno pokažete znamenje na Kapitolu, če se pripravljate na vojno? Mar še upoštevate fecialno pravo? Še zahtevate odvzete stvari nazaj z zahtevo po odškodnini? Mar ob približevanju prelomnemu trenutku pod Marsovim vodstvom svoje upanje $\mathrm{v}$ boju še vedno stavite vanj in pri tem prerokujete iz konice kopja? Mar pri zasedanju položajev ohranjate starodavne zakone? In pri darilih in darovih Cincijeve? Pri omejevanju izdatkov odredbe cenzorjev? Mar pri svetiščih penatov in drugih nebeščanov vzdržujete večni ogenj? Posvečujete mize tako, da nanje postavite solnice in podobe bogov? Mar ob porokah pogrinjate postelje s togo in kličete genije mladoporočencev? Mar gladite lase nevest z nevestinim »kopjem«? Nosite obleke deklet v tempelj Deviške Fortune? Delajo vaše matere v notranjosti hiše in tako izpričujejo svojo marljivost? Se vzdržijo pitja vina? Še obstaja pravica sorodnikov in bližnjih, da jih poljubijo in tako potrdijo, da so trezne in vzdržne?

Ta precej nevtralni prikaz nekaterih pojavov, značilnih za zgodnja obdobja rimske zgodovine, ${ }^{23}$ je sočasno dober most k naslednjemu razdelku, ko se bom posvetil tistim vidikom zgodnje rimske zgodovine, ki so v apologetskem slovstvu opremljeni z izrazitim negativnim predznakom. Zdelo se mi je primerno, da namenim doslej obravnavanim vsaj pogojno pozitivnim rabam zgledov iz časa kraljev in republike nekaj več prostora, medtem ko bom to drugo plat osvetlil le z nekaj najznačilnejšimi primeri.

\section{III.}

Kakor je bilo že omenjeno in razvidno iz Avguštinovih besed čisto na začetku prispevka, sta bila v očeh kristjanov s kopreno mita pokrita zgodnja zgodovina Rima in njeno republikansko nadaljevanje še bolj kot njihova cesarskodobna sedanjost zaznamovana s poganskim bogočastjem, spričo česar je bil njihov zadržan odnos do njiju precej na dlani, ne glede na morebitne pozitivne danosti, o katerih je bil govor do sedaj.

Še več, ravno prva stoletja obstoja rimske države od njenih zelo skromnih začetkov naprej so predstavljala argumentacijsko jedro slovitega rimskega kreda, v skladu s katerim so bogovi skromni pastirski naselbini ob Tiberi

${ }^{23}$ Pri čemer von Haehling, "Die römische Frühzeit«, 196 z op. 56, upravičeno opozarja, da je Arnobij zglede bolj ali manj naključno nametal (s čimer je dober zgled za siceršnje ravnanje apologetov z zgodovinskim gradivom iz obravnavane dobe) in se ni zavedal prelomnosti nekaterih sprememb (kot je denimo prenehanje neposrednih volitev konzulov). 
omogočili tolikšno rast prav zaradi izjemne pobožnosti in zglednega življenja njenih prvih prebivalcev. ${ }^{24}$ Druga pomembna okoliščina je kajpak bila, da so poganski Rimljani v pionirskih časih svoje preteklosti hkrati iskali izvor večine kultov, zaradi neupoštevanja katerih so trdo prijemali kristjane.

Šolski primer poganskega zaupanja $\mathrm{v}$ kredo in $\mathrm{z}$ njim povezanih očitkov »odpadniškim « pripadnikom Kristusovega nauka polaga Minucij Feliks v usta še nespreobrnjenemu Ceciliju ob začetku svojega Oktavija:

Inde adeo per universa imperia, provincias oppida videmus singulos sacrorum ritus gentiles habere et deos colere municipes, ut Eleusinios Cererem, Phrygas Matrem, Epidaurios Aesculapium, Chaldaeos Belum, Astarten Syros, Dianam Tauros, Gallos Mercurium, universa Romanos. Sic eorum potestas et auctoritas totius orbis ambitus occupavit, sic imperium suum ultra solis vias et ipsius oceani limites propagavit, dum exercent in armis virtutem religiosam, dum urbem muniunt sacrorum religionibus, castis virginibus, multis honoribus ac nominibus sacerdotum, dum obsessi et citra solum Capitolium capti colunt deos, quos alius iam sprevisset iratos, et per Gallorum acies mirantium superstitionis audaciam pergunt telis inermes, sed cultu religionis armati, dum captis in hostilibus moenibus adhuc ferociente victoria numina victa venerantur, dum undique hospites deos quaerunt et suos faciunt, dum aras extruunt etiam ignotis numinibus et Manibus. Sic, dum universarum gentium sacra suscipiunt, etiam regna meruerunt. (Minucius Felix, Octavius 6.1-3)

Zato torej vidimo, da imajo po vseh cesarstvih, pokrajinah, mestih posamezni narodi sveta obredja in častijo narodne bogove, tako Elevzinci Cerero, Frigijci Mater, Epidavrijci Eskulapa, Kaldejci Bela, Sirci Astarto, Tavrijci Diano, Galci Merkurja, Rimljani pa vse te. Tako je njihova moč in oblast zavzela ves krog sveta, tako je razširila svoje vladarstvo onstran sončeve poti in mejá samega oceana. Tudi pod orožjem namreč uresničujejo vrlino pobožnosti, mesta utrjujejo z obhajanjem svetih obredov, s pomočjo čistih devic, s številnimi častmi in imeni svečenikov. Da, ko so bili oblegani in je bilo zavzeto vse razen Kapitola, so častili bogove, ki bi jih bil kdo drug, razsrjen, že zavrgel, in skozi bojne vrste Galcev, ki so se čudili drznosti praznoverja, so šli naprej - ne oboroženi s sulicami, marveč oboroženi s pobožnim čaščenjem. Ko zavzamejo sovražno obzidje, že v času trajanja zmagovitega divjanja častijo premagane bogove. Povsod iščejo tuje bogove in jih delajo za svoje, oltarje gradijo celo neznanim božanstvom in manom. Tako si s tem, ko častijo svete stvari vseh narodov, prislužijo tudi kraljestva. ${ }^{25}$

${ }^{24} \mathrm{O}$ tem kredu in težavah apologetov z njim odlično piše Heck, Mè theomáchein, predvsem $30-46$.

25 Navedeno v rahlo spremenjenem prevodu Jasne Hrovat. 
Na prvi pogled je očitno, da sta se ob takšnih stališčih apologetom ponujala dva primerna odgovora (Arnobijevega, češ da resničnemu božanstvu ne more biti zares mar za kult, puščam tu ob strani). Blažji je bil opozorilo na dejstvo, da so veliko pred Rimljani obstajala močna in dolgotrajna kraljestva, ki pa že spričo svoje časovne umeščenosti seveda niso mogla temeljiti na (pravilnem) čaščenju za uspeh Rimljanov domnevno merodajnih bogov. ${ }^{26}$ Takšno stališče je bilo kristjanom zaradi njihove zgoraj omenjene podobe zgodovine, $v$ kateri so vsaj od Ireneja odmevali toni prenosa kraljestev, ${ }^{27}$ blizu. A za učinkovitejše orožje se je izkazalo dokazovanje, da je Rim sicer prišel do velikega in mogočnega imperija, toda ne s kakšno izjemno pobožnostjo in krepostnostjo, pač pa ravno narobe, $\mathrm{z}$ brezobzirnostjo, zločinskostjo in komolčarstvom.

Ker je bilo tako, so morala zelo v ospredje stopiti čisto prva leta (mitološke) preteklosti Rima, saj je bilo moč z dejanji njegovih pionirjev najbolje podkrepiti takšno podobo vzpona imperija. Zaradi tega bralec apologetskih tekstov tudi pridobi v celoti morda ne povsem upravičen vtis o popolnoma negativnem pojmovanju prvih rimskih stoletjih pri krščanskih piscih, saj je bil v prejšnjem razdelku več kot razviden pomemben delež drobcev, ki omogočajo drugačne interpretacije. Seveda omenjeni drobci niso vidni do te mere kot bruhanje ognja zoper zgodnje Rimljane. Na podoben način se pojavi že omenjeni vtis o poudarjenem mestu obdobja kraljestva na račun republike; sceno zares $\mathrm{v}$ veliki meri obvladujeta veliki figuri prvih kraljev Romula in Nume Pompilija.

Za ponazoritev pravkar povedanega si bo dovolj ogledati dva najbolj tipična zgleda. Prvi je Tertulijanov in sodi v njegov spis De spectaculis. Nekoliko prej kot se loti dokazovanja izvorov gledališča $\mathrm{v}$ poganskem kultu, $\mathrm{v}$ podobnem kontekstu vzame na muho druge oblike zabave, tudi Neptunu namenjene ludi Consuales ali Consualia. Ob tem ne zamudi priložnosti, da ne bi poudaril prav zločinske narave zgodnjega Rima in njegovega ustanovitelja:

Exinde ludi Consualia dicti, qui initio Neptunum honorabant. Eundem enim et Consum vocant. Dehinc Ecurria ab equis Marti Romulus dixit; quamquam et Consualia Romulo defendunt, quod ea Conso dicaverit deo, ut volunt, consilii, eius scilicet, quo tunc Sabinarum virginum rapinam militibus suis in matrimonia excogitavit. Probum plane consilium et nunc quoque inter ipsos Romanos iustum et licitum, ne dixerim penes deum. Facit enim et hoc ad originis maculam, ne bonum existimes quod initium a malo accepit, ab impudentia a violentia ab odio, a fratricida institutore, a filio Martis. (Tertullianus, De spectaculis 5.5 in sl.)

Tako se igre, ki so od začetka proslavljale Neptuna, imenujejo Konzualije. Slednjemu namreč pravijo tudi Konzus. Zato je Romul Marsu posvetil Ekurije po besedi za konje, čeprav mu prav tako pripisujejo Konzualije,

26 Prim. Tertulijan, Apologeticum 26.2-3, in Minucij Feliks, Octavius 25.12.

27 Gl. denimo Marrou, »Geschichtsphilosophie«, 766. 
ker da jih je namenil Konzusu, kot zatrjujejo, božanstvu nasveta, kajpak tistega, po katerem se je takrat za poroko svojih vojakov domislil ugrabitve sabinskih deklet. Zagotovo pošten in med Rimljani samimi, da ne rečem celo pri bogu, še zdaj pravičen in dopusten načrt. To je namreč storil tudi zato, da bi omadeževal izvor in ne bi mogli misliti, da je dobro kaj, kar izvira iz slabega, iz nesramnosti, iz nasilja, iz sovraštva, od bratomorilskega ustanovitelja, od Marsovega sina.

Tam, kjer vidijo obtoževalci kristjanov nenavadno krepostnost, ugleda afriški apologet samo zlo, še več, zlo, ki naj bi si ga izmislil bog Neptun. Seveda v obravnavanem kontekstu iz dejstva, da je Consualia vzpostavil bratomorilec, nasilnik, ugrabitelj in sin poganskega boga Marsa, izpelje predvsem sklep, da ne morejo biti igre same nič prida. A nekaj podobnega bi se po apologetovo verjetno dalo reči tudi o na podobnih temeljih zgrajenem imperiju, na katerega je tako ponosen Cecilij, kot celoti. ${ }^{28}$

Najhujšo in najbolj sistematično zavrnitev pri zgodnjih apologetih pa je obravnavani nosilni steber rimskega poganskega kreda doživel tam, kjer je po Cecilijevih ustih ravno tako doživel najlepši slavospev. V petindvajsetem poglavju Oktavija naslovna oseba dialoga namreč odločno zavrne sogovornikove navedbe in jih $\mathrm{v}$ celoti demontira - kot že Tertulijan z zgledi povsem $\mathrm{z}$ začetka rimske zgodovine. Oktavijeva kritika je tako silovita, da na prvi pogled ne dopušča veliko prostora za kakršno koli pristajanje na rimska izročila: ${ }^{29}$

At tamen ista ipsa superstitio Romanis dedit, auxit, fundavit imperium, cum non tam virtute quam religione et pietate pollerent. Nimirum insignis et nobilis iustitia Romana ab ipsis imperii nascentis incunabulis auspicata est! Nonne in ortu suo et scelere collecti et muniti immanitatis suae terrore creverunt? Nam asylo prima plebs congregata est: confluxerant perditi, facinerosi, incesti, sicarii, proditores, et ut ipse Romulus imperator et rector populum suum facinore praecelleret, parricidium fecit. Haec prima sunt auspicia religiosae civitatis! Mox alienas virgines iam desponsatas, iam destinatas et nonnullas de matrimonio mulierculas sine more rapuit, violavit, inlusit, et cum earum parentibus, id est cum soceris suis bellum miscuit, propinquum sanguinem fudit. Quid inreligiosius, quid audacius, quid ipsa sceleris confidentia tutius? Iam finitimos agro pellere, civitates proximas evertere cum templis et altaribus, captos cogere, damnis alienis et suis sceleribus adolescere cum Romulo regibus ceteris et posteris ducibus communis est. Ita quicquid Romani tenent, colunt, possident, audaciae praeda est: templa omnia de manubiis, id est

${ }_{28}$ Za podrobnejšo analizo odlomka gl. von Haehling, »Die römische Frühzeit«, 189-91, kjer je najti tudi opozorilo na dejstvo, da je Tertulijan v tem spisu bistveno ostrejši do Romula kot v Apologetiku.

29 Von Haehling, »Die römische Frühzeit«, 193. 
de ruinis urbium, de spoliis deorum, de caedibus sacerdotum. (Minucius Felix, Octavius 25.1-5)

Pa vendar je prav to praznoverje Rimljanom dalo, razširilo in utrdilo imperij, kajti bili so močni ne toliko zaradi kreposti kot zaradi verovanja in pobožnosti. Brez dvoma je bila znamenita in plemenita rimska pravičnost ob ugodnih znamenjih spočeta že v zibelki rojevajočega se imperija. Toda ali ni že v samem začetku, ko jih je zbral in utrdil zločin, raslo njihovo število zaradi strahu pred svojo lastno divjostjo? Kajti prvo ljudstvo je bilo zbrano v zavetišču: skupaj so se zgrinjali izgubljenci, zločinci, krvoskrunitelji, zavratni morilci, izdajalci, in da bi Romul sam, vladar in voditelj, prekašal svoje ljudstvo glede zločina, je zagrešil bratomor. To so prvi začetki pobožne države! Kmalu nato je - kar prej ni bil običaj - ugrabil, storil silo in oskrunil tuje device, že zaročene, oddane, nekatere zakonske žene, in se zapletel v vojno z njihovimi starši, to je s svojimi tasti, prelil je kri sorodnikov. Kaj je bolj brezbožno, kaj bolj nesramno, kaj je varnejše kot zaupanje v zločin? Sosede pregnati s polj, najbližja mesta $\mathrm{z}$ njihovimi templji in oltarji uničiti, jih gnati v ujetništvo, krepiti se s tujimi nesrečami in lastnimi zločini, to je torej nauk, ki je skupen Romulu in ostalim kraljem ter kasnejšim voditeljem. Kar koli torej Rimljani imajo, obdelujejo, posedujejo, je plen predrznosti: vsi templji izvirajo iz bojnega plena, to je iz ruševin mest, od ropa bogov, ubojev svečenikov.

Minucij Feliks še bistveno zaostri kritiko verjetnega predhodnika. Na začetek rimske zgodovine in pred Romulov bratomor drugače kot on postavi zbiranje vse mogoče sodrge v novi naselbini, ${ }^{30}$ kar daje ton vsemu nadaljevanju in takoj postavi Cecilijev argument o krepostnosti prednikov v precej čudno luč. Tudi v nadaljevanju bratomor in ugrabitev Sabink zabeli s še precej bolj sočnimi komentarji od tistih v spisu De spectaculis. Slednjič vse skupaj privede do zmagoslavnega zaključka z odgovorom na sogovornikovo vzneseno (in v besedilu prej navedeno) hvalnico inkluzivnosti rimskega panteona. Da, pravi Oktavij, Rimljani so res prevzeli tuje bogove, ampak še prej so porušili ali oskrunili njihove templje in pobili njihove svečenike.

Ravno na podlagi tovrstnih mest v latinski krščanski apologetiki prevladuje vtis o mračni podobi zgodnje rimske zgodovine med kristjani. Toda niti ob petindvajsetem poglavju Oktavija ne smemo izgubiti izpred oči izrazito prigodnega značaja omemb tega obdobja. Enako kot Minucij Feliks na pravkar citiranem mestu rohni zoper stare rimske junake, jih proti koncu svojega spisa - kakor je bilo razvidno - venča s slavo kot predhodnike krščanskih mučencev.

30 Skromen nastavek za takšno oceno je lahko našel celo pri Liviju, ki prve prebivalce Rima v 1.8.5 imenuje obscura atque humilis multitudo. 
Zato ni presenetljivo, da iz iste apologetske dediščine izvirata tako negativni prikaz rimske republike pri Oroziju kot precej bolj pozitivna podoba pri njegovem delodajalcu Avguštinu in že prej celo odločna naslonitev na z vrednotami stare republike prežeto senatno izročilo ${ }^{31}$ pri Laktanciju.

\section{BIBLIOGRAFIJA}

Corsaro, Francesco. »Le mos maiorum dans la vision éthique et politique du De mortibus persecutorum. « V: Lactance et son temps: Recherches actuelles, ur. J. Fontaine in M. Perrin, 25-49. Pariz: Éditions Beauchesne, 1978.

D’Elia, Salvatore. "Storia e teologia della storia nel De civitate Dei.« V: La storiografia ecclesiastica nella tarda antichità, ur. S. Calderone, 391-481. Messina: Centro di Studi Umanistici, 1980.

Edwards, Mark. »The Flowering of Latin Apologetic: Lactantius and Arnobius.« V: Apologetics in the Roman Empire, ur. M. Edwards et al., 197-221. Oxford: Oxford University Press, 1999.

Fiedrowicz, Michael. Apologie im frühen Christentum: Die Kontroverse um den christlichen Wahrheitsanspruch in den ersten Jahrhunderten. Paderborn: Ferdinand Schoeningh, 2000.

Forsythe, Gary. A Critical History of Early Rome: From Prehistory to the First Punic War. Berkeley, Los Angeles in London: University of California Press, 2005.

Haehling, Raban von. »Die römische Frühzeit in der Sicht frühchristlicher Autoren.« $\mathrm{V}$ : Rom und das himmlische Jerusalem: Die frühen Christen zwischen Anpassung und Ablehnung, ur. R. von Haehling, 184-204. Darmstadt: Wissenschaftliche Buchgesellschaft, 2000.

Heck, Eberhard. ME THEOMACHEIN oder die Bestrafung des Gottesverächters. Frankfurt/Main, Berlin in New York: Peter Lang, 1987.

Inglebert, Hervè. Les Romains chrétiens face a l'histoire de Rome: Histoire, christianisme et romanités en Occident dans l'Antiquité tardive (IIIe-Ve siècles). Pariz: Institut d'Études Augustiniennes, 1996.

Kocijančič, Gorazd, ur. Logos v obrambo resnice: Izbrani spisi zgodnjih apologetov. Celje: Mohorjeva družba, 1998.

Koep, Leo. "Antikes Kaisertum und Christusbekenntnis im Widerspruch.« V: Das frühe Christentum im römischen Staat, ur. R. Klein, 302-36. Darmstadt: Wissenschaftliche Buchgesellschaft, 1971.

Leppin, Hartmut. »Politik und Pastoral - Politische Ordnungsvorstellungen im frühen Christentum.« V: Die Anfänge des Christentums, ur. F. W. Graf in K. Wiegandt, 308-38. Frankfurt/Main: Fischer Taschenbuch Verlag, 2009.

Marrou, Henri-Irénée. »Geschichtsphilosophie.« RAC X (1978): 752-79.

Maver, Aleš. »Pota in stranpota v latinski krščanski apologetiki.« Keria 9 (2007): 25-44.

Meinhold, Peter. Geschichte der kirchlichen Historiographie I. Freiburg in München: Karl Alber, 1967.

O’Daly, Gerard. Augustine's City of God: A Reader's Guide. Oxford: Oxford University Press, 2004.

Rohrbacher, David. The Historians of Late Antiquity. London in New York: Routledge, 2002.

31 O tem zlasti Corsaro, »Le mos maiorum«, 25-49. 
Simmons, Michael Bland. Arnobius of Sicca: Religious Conflict and Competition in the Age of Diocletian. Oxford: Oxford University Press, 1995.

Thraede, Klaus. »Euhemerismus.« RAC VI (1966): 877-89.

Winkelmann, Friedhelm. »Historiographie.« RAC XV (1990): 724-65.

Zecchini, Giuseppe. "Latin Historiography: Jerome, Orosius and the Western Chronicles." V: Greek and Roman Historiography in Late Antiquity: Fourth to Sixth Century, ur. G. Marasco, 319-45. Leiden in Boston: Brill, 2003.

\section{VETERES IGITUR PRIMIQUE ROMANI: DAS RÖMISCHE KÖNIGREICH UND DIE RÖMISCHE REPUBLIK IN DER FRÜHEN LATEINISCHEN CHRISTLICHEN APOLOGETIK}

\section{Zusammenfassung}

Der Aufsatz behandelt die Thematisierung der Ereignisse und Personen aus der Frühzeit der römischen Geschichte bei den christlichen Apologeten Tertullian, Minucius Felix und Arnobius. Obwohl eine verhältnismäßig systematische Schilderung des römischen Königreiches und der römischen Republik im lateinischen apologetischen Schrifttum erst am Anfang des 5. Jahrhunderts mit den beiden grossen Werken des Augustinus und Orosius gab, konnte sie sich in vielen Hinsichten auf etliche Themen und Ideen, die bereits bei den Vorgängern aus dem 3 . und 4. Jahrhundert Aufmerksamkeit fanden, stutzen.

Dabei zeigt wenigstens der erste Blick zwei bedeutende Merkmale des Umgangs der frühen Lateinisch schreibenden Apologeten mit der Frühzeit Roms. Erstens ist das Königreich - ganz besonders die ersten beiden Könige - besser vertreten als die Republik, und zweitens beherrscht die negative Beurteilung dieser Epoche das Bild. Das kann kaum verwundern, denn die Frühzeit der römischen Geschichte war ja auch der Ursprung der Mehrheit der kultischen Vorschriften, die christliche Apologeten zu bekämpfen versuchten. Außerdem bildeten die Beispiele aus dieser Zeit das Rückgrat des berühmten römischen Credo, das die besondere Verbindung zwischen Rom und seinen Göttern zu beweisen schien.

Trotzdem konnte, wie sich in der Abhandlung zunehmend zeigt, insbesondere die Epoche der römischen Republik durchaus auch eine Menge an positiv verwendbaren Beispielen für die Apologeten liefern. Sie sind zwar nicht so auffällig wie die negativen Seiten des Anfangs Roms und wirken vielmals äußerst zufallsbedingt und willkürlich.

Dennoch kann man etliche Gebiete aussondern, wo die Apologeten (vor allem republikanische) Themen vermehrt einsetzen. Zuerst bewunderten auch sie die angebliche moralische Überlegenheit und moralische Strenge der frühen Römer. Diese Linie, die auch die Treue der Heiden ihrer Zeit zu den Sitten der Vorfahren in Frage stellen sollte, führt von Tertullian direkt zu der im Wesentlichen doch 
bejahenden Beurteilung dieser frühen Epoche in der Geschichte Roms im fünften Buch des Gottesstaates.

Theologisch interessanter ist wahrscheinlich der Versuch, mit den Beispielen der tugendhaften römischen Helden um das Verständnis für das Phänomen der christlichen Blutzeugen zu werben. Arnobius geht da noch einen Schritt weiter als Tertullian und Minucius Felix und versucht sogar, das Leiden Christi mit den republikanischen (und griechischen) Parallelen verständlicher zu machen.

Schließlich lieferte das römische Altertum auch Beispiele für juristische und religiöse Neuerungen, die Christen von einem der bedeutendsten und schwerwiegendsten Vorwürfe der heidnischen Umwelt entlasten sollten. Wiederum macht vor allem Arnobius davon Gebrauch.

Am Ende darf man sagen, dass der Umgang der in dem Aufsatz behandelten Apologeten mit der römischen Frühzeit nicht nur das negative Bild des Königreiches und vor allem der Republik bei Orosius, sondern auch die wesentlich helleren Töne bei Augustinus und vor allem Laktanz vorbereitete. 